\title{
What Impacts IPO Underpricing? Evidence from Dhaka Stock Exchange
}

\author{
Maria Hossain Sochi $^{1} \&$ Raisul Islam ${ }^{1}$ \\ ${ }^{1}$ University of Dhaka, Bangladesh \\ Correspondence: Maria Hossain Sochi, University of Dhaka, Bangladesh. E-mail: maria_sochi@yahoo.com
}

Received: January 18, 2018

Accepted: February 20, 2018

Online Published: February 25, 2018

doi:10.5539/ijbm.v13n3p88

URL: https://doi.org/10.5539/ijbm.v13n3p88

\begin{abstract}
Initial Public Offering (IPO) is an important and widely popular research topic among many researchers in finance discipline. This study is prepared to identify the connection among various empirical studies and theories regarding underpricing of IPO in the stock market of Bangladesh. We have chosen the time frame of June 2011 to June 2016 at DSE to conduct the research. In this study, ordinary least square (OLS) regression method is used to identify in what extent the dependent and the independent variables are related in the level of underpricing. The results of the study disclose that oversubscription rate, offer size have substantial influence in IPO underpricing at DSE. On the other hand, offer time and size of the firm do not have significant influence on the level of underpricing. These variables are very significant and play important roles with the level of underpricing at DSE and it shows relation to signaling theory, information asymmetry theory and agency cost theory.
\end{abstract}

Keywords: Dhaka stock exchange, determinants of underpricing, initial public offering, underpricing

\section{Introduction}

\subsection{Rational of the Study}

Initial Public Offering (IPO) is an important and widely popular research topic among many researchers in finance discipline. There are various theories regarding this issue explaining it in different aspects. Researchers have documented several studies and empirical evidence regarding this topic which identifies IPOs can be underpriced both in developing and developed countries (Islam and Ali 2010). Ritter (1984) argued that underpricing occur when a firm decides to go public. IPOs are said to be underpriced, when the price of the IPO goes above the offer price of that IPO in its after-market where it can be traded immediately. There are several theories and models provided by significant number of authors. The core intention of this research study is to identify the price behavior of IPOs of the Dhaka Stock Exchange in the period of June 2011- June 2016. This paper will contribute to the current literature of IPOs in the emerging market and specifically that in Dhaka Stock Exchange with regard to the underpricing and the stock price behavior subsequent to IPOS. The general objective is to detect various theories which are related to the level of underpricing taken place in DSE. More specifically we have tried to find the variables that affect underperformance of IPO in the short time period. We have also tried to identify the trend of underperformance of IPO in Bangladesh Stock Market.

Over the last decade the capital market of Bangladesh has evolved and graduated from a very nascent stage to a developing stage with the implementation of new regulatory enforcements and infrastructural development. Dual listing is allowed for the initial public offerings in this market. It has been observed that $95 \%$ listed IPOs in Chittagong stock exchange are also listed at DSE. As a result, this study will be helpful to identify the extent of underpricing and reasons behind it in Bangladesh.

\subsection{Review of the Literature}

Initial Public Offerings (IPO) has been a significant topic for research among various renowned researchers. There are significant number of works and empirical evidence regarding this topic in the finance discipline. These research shows significant amount of evidence that underpricing IPOs have become an important concern among the investors. Stoll \& Curly in (1970) identified a tendency that the IPOs are providing abnormal return to the investors who are purchasing it at the initial offerings. Miler and Really (1987) identified that, there are significant effort of modifications and extensions used in this issue to examine the abnormality of IPO underpricing among the investors. 
There are documents that provides empirical evidence that the levels of underpricing in IPOs in Dhaka Stock Exchange (Islam and Ali 2010). It is found that there exist very substantial relationship between the offer size and company's size. Regression analysis clearly revealed this significant relationship between these two variables. The results from the regression reveals that, age of the firm and the offer timing do not have any significance in the level of underpricing.

Bansal and Khanna in (2012) identified the presence of a substantial difference when they worked with the underpricing level. They mainly conducted their research on Bombay Stock Exchange. They had taken the time frame of April 1998 to December 2012. In this time frame they have found that the extent of underpricing can be explained by several factors. Among them firm's ownership structure, firm's age and the market capitalization are significant. In 2009, Sohail and Raheman investigated the connection between two important offerings which are known as pre and post initial public offerings.

They have conducted their research on Karachi Stock Exchange. Their results showed positive relation to the interest of the investors in the pre initial public offerings demand to the offer ratio.

There are various empirical evidence provided by Kumar \& Tsetsekos in (1992), Titman and Trueman (1986) on this issue. They have identified the evidence that support the model that many renowned underwriters have linked to comparatively less risky IPOs. It their investigation it is found that, IPO which has a minimum level of market value has significant relation with the quality of the underwriter. So they have documented in their research that IPOs have little chance to become underpriced if the company choose quality investment banker. There are many research work conducted on signaling theory of underpricing (Allen \& Faulhaber 1989).Other prominent research works were conducted by Griblatt \& Hwang in (1989) and Ibbotson in (1975). They identified the harsh part of the underpricing the IPOs. They have documented that, IPOs are mainly underpriced for fraudulent purpose. It will provide a signal to the general investors about the good taste of the IPOs so that they can the same firm can sold their future underwritings at a very high price to the common investors. Various theories were also developed to increase the stock market efficiency. Major works were conducted by Benveniste and Spindt in (1989). They mainly established a theory regarding this market efficiency. This theory is considered as the pioneer of creating the book building method of IPO underwriting. This method has achieved popularity and is taken by many countries including developing economies around the world. Third world country like Bangladesh has taken the method but to a little extent. This model helps to identify the actual demand for the new issue and also the condition of the issuing firm at that time. Underwriters can use the help of this method so that they can reduce the underpricing level in the stock market. This will help to adjust the offer price with demand created in the market. Agency theory has also gained popularity in this aspect. This theory has many impact on this IPO issue. Research work on this issue were conducted by (Robinson and Peng 2004). They have conducted their research on US market which is considered as the largest stock market around the world. As a result they had to take a large sample. Their sample size was 3090 IPOs of US market. They had taken a ten years large time frame which was January 1987 to December 1999. They have identified that, US market usually have documents regarding IPO owners are high previously. This will signal the management of the issuing companies always expect higher future revenue which increased the agency cost associate with entrenchment.

This signaling model was also identified by other researchers. Allen and Faulhaber in (1989), Welch (1989) were also worked on this signaling model. They have also identified the same factors that, IPOs are underpriced to deceive the common investors so that they can sell their future underwritings at a higher price. Another important theory regarding this issue is Agency Theory. Robinson and Peng in (2004) worked on this theory. They have identified that, underwriters and the investors have different mindset and they have different level of interests in the underwritings. Robinson and Peng have conducted a research with a sample size of 3080 IPOs of US stock market. Their time frame was similar which is from January 1988 to December 1999. Their results showed that, management of the underwriting or the issuer always expect higher revenue in future. This demand goes against the interest of the investors thus generates higher agency cost. Rock (1986) indicated adverse selection model. This model helped to find out the information asymmetry situation between various investors who may be both informed and uninformed. Through this situation lemon problem occurs as the uninformed investors know nothing but the general information about the IPO which we call mean value. So they end up with bad IPOs. Another important theory in IPO underpricing is information asymmetry. Allen and Fauhaber (1989), Booth \& Smith (1989) developed this information asymmetry theory. In this theory they have documented that, the issuers and the underwriters have better information about the market and also about their company. Therefore the investors need to be compensated by the issuers on the ground of the information asymmetry. As the underwriters have inside information, they can easily manipulate the offerings at the cost of the common investors. 


\section{Methodological Framework}

In this study we have used ordinary least square (OLS) method to predict or understand our dependent variable. This OLS method is used to predict the unknown variables of our linear regression models. The main purpose of using this method is to minimize the sum of the squared differences between the observed variables and the predicted value for the dependent variable. OLS regression model provides the optimum estimates from the possible parameters under the assumptions that we have used for processing our models.

In this study, we have used two regression models using the same dependent variable. Here, in model 1 we have used size of the firm along with offer time and over subscription rate as dependent variable. But in model 2, we have used offer size instead of size of the firm as dependent variable. In order to separate this two dependent variables, we have created two econometric model. The reason is that, if we use offer size and size of the firm in a same econometric model, it will lead to multicolinearity problem. Using this two variables in a same model will lead to misleading results to determine how well our independent variable can predict the dependent variables. It also provides less reliable probability values for market adjusted abnormal return (MAR).

\subsection{Variable Selection \& Hypothesis}

\subsubsection{Dependent Variable}

Market adjusted return (MAR) is considered as the dependent variable. We have calculated MAR in the following way. It has relevance with proper methodology. We have calculated underpricing level on the basis of percentage change with respect to offer price and closing pricing. In the secondary market which have used previously.

\section{First day underpricing $($ Traditional basis $)=(($ closing price-offer price $) /$ offer price $)) * 100$}

In order to make the initial return of a share similar and comparable to another share it is necessary to quote the initial return in relation to the share's issue price. Then we have to multiply it with 100 to get a proportional return. In the following way we have calculated MAR that is market adjusted return:

At first, we have calculated return on security i. We have used the following formula:

where $\mathrm{Ri}=(\mathrm{P} 1-\mathrm{P} 0) / \mathrm{P} 0$ in which, $\mathrm{Ri}=$ return on $\mathrm{i}$ security, $\mathrm{P} 1=$ Price of $\mathrm{i}$ security on first listing day, $\mathrm{P} 0=$ offer price of i security.

$$
\mathbf{R i}=(\mathbf{P 1}-\mathbf{P 0}) / \mathbf{P 0}
$$

Secondly, we have calculated the index return on corresponding days. Where, $\mathrm{Mi}=(\mathrm{Ii}-\mathrm{I} 0) / \mathrm{I} 0$. In which $\mathrm{Mi}=$ market return on the ith day. $\mathrm{Ii}=$ closing index of DSE at the listing day. $\mathrm{I} 0=$ closing index of DSE at offer day.

$$
\mathbf{M i}=(\mathbf{I i}-\mathbf{I 0}) / \mathbf{I 0}
$$

The raw return is also known as security return. It is used to determine the IPO return for each share on the level of market adjustment. Here is the formula:

$$
\text { MAR }=\{100 *[(1+\mathbf{R i}) / 1+\text { Mi })-1]\}
$$

\subsubsection{Explanatory Variable}

Size of the firm Kiyamaz (2000), Bhabra \& Pettway (2003) identified an inverse relationship between size of the firm and the level of underpricing. If the size of the firm is larger, there will be lower uncertainty that the value of the firm will go down at listing time.

\section{H1: Initial Underpricing and size of the firm are negatively related}

Offer Size It is argued by Carter and Manaster (1990) that investors use the size of the offer to measure the performance of the IPOs. They have found a negative relationship between offer size and level of underpricing.

\section{H2: Offer size has a negative relationship with the level of underpricing.}

Offer Time It is identified by Balwinder Singh (2003) that offer timing is a very significant determine in underpricing IPOs. The more offer timing is the more road show can be arranged as a result underpricing will go high.

\section{H3: Offer timing has positive elation with initial underpricing.}

OSR It is identified by Dawson (1984) that, pre IPO investors require after market performance influences. In the very first day, an upward pressure exists as it is demanded by the investors. Over subscription mainly helps to identify the investor's demand. 


\section{H4: Over subscription rate has a positive link with the initial public offering}

The variables are calculated as follows:

\begin{tabular}{|c|c|c|c|}
\hline Character & Variables & Measure (proxy) & Prior empirical work \\
\hline MAR & $\begin{array}{l}\text { Market adjusted } \\
\text { return }\end{array}$ & Market Adjusted Abnormal Return & $\begin{array}{l}\text { Sohail and Nasr(2007),Bansal \& } \\
\text { Khanna (2012) }\end{array}$ \\
\hline SOF & Size of Firm & In( Net Asset Value found in the listing year ) & Islam, \& Ahmad (2010) \\
\hline OS & Offer Size & In(Offer price times the number of shares) & $\begin{array}{l}\text { Beatty and Ritter(1986), } \\
\text { Ibbotson(1984), }\end{array}$ \\
\hline OT & Offer Timing & $\begin{array}{l}\text { It indicates the differences between offer and listing date } \\
\text { (which are calculated in days) }\end{array}$ & Islam, \& Ahmad (2010) \\
\hline OSR & $\begin{array}{l}\text { Over Subscription } \\
\text { Rate }\end{array}$ & Over subscription and offer size in percentage form. & Kumar \& Singh (2008) \\
\hline
\end{tabular}

\subsection{Research Design}

The market that was selected for our analysis is Dhaka stock Exchange. It is the biggest stock exchange of Bangladesh having 90 times more trade value and 114 times more trade quantity than the other stock market of the country that is Chittagong Stock Exchange. Dhaka Stock Exchange also has approximately twice the number of listed stock than CSE. Most of the Investors of the country are related with DSE and information shows up quite fast in the price. Being in the center of the Capital of the country, it also gets the most amount of notice. So it is logical to select DSE as the market to take data from to perform research.

Sources of Data

Data is primarily collected from the website of DSE. The price compilation is collected from DSE news archive. Daily price is used to reflect most accurate changes in the market.

Sampling and the Inclusion Criteria

The IPOs taken are all within a 5 years' timeframe from June 2011 to June 2016. The IPOs include only shares of companies newly listed and offering that is "Initial" but not "Repeat". Mutual funds are left out because it may lead to double count the market, and also as mutual funds are actively manage funds, that will always tend to give a biased result towards upside. Banks and Financial Sector are also excluded. We have only taken IPOs from non-financial sector.

Research Model Development

The IPOs taken are all within a 5 years' timeframe from June 2011 to June 2016. We have only taken IPOs from non-financial sector. We have taken a sample of 50 IPOs listed in Dhaka Stock Exchange form June 2011 to June 2016. Simple linear regression model is used to analyze the data. Variables are selected in this paper is based on prior theories and empirical evidences.

The econometric model can be made functional in the following way:

Here,

$$
\begin{aligned}
& \text { MAR }=\alpha+\beta_{1}\left(\text { OT) }+\beta_{2}(\text { SOF })+\beta_{3}(\text { OSR })+\mu\right. \\
& \text { MAR }=\alpha+\beta_{1}\left(\text { OT) }+\beta_{2}(\text { OS })+\beta_{3}(\text { OSR })+\mu\right.
\end{aligned}
$$

Here

MAR $=$ Market Adjusted Return

OS = Offer Size

OT $=$ Timing of Offer

$\mathrm{SOF}=$ Size of Firm

OSR $=$ Over Subscription Rate

\section{Review of IPO Underpricing in Dhaka Stock Exchange}

Initial public offering underpricing means, price of the IPO goes very high when it is traded for the first time. It is called initial return or it can be termed as first day return of IPO. We can use the following method:

Underpricing IPO $=($ First day closing price- Offer price $) /$ Offer price* $100 \%$ 
This closing price on the first day indicates the willingness of the investors and their motivation to pay regarding the share of the firm. The IPO will be underpriced, if the offer price is less than IPO's closing price. IPOs are underpriced often because of uncertainty related to liquidity and the price level at which the stock will trade. If the IPOs are not that much liquid and not predictable to a certain level then it will be more underpriced, as it will have to compensate the people to invest there for the risk they have taken in the market.

\subsection{Difference between Offer Price and Face Value}

Offer price of IPO has substantial level of difference from its face value. During our time period, out of 50 companies in Dhaka Stock Exchange 32 IPO issued at premium with a mean of $22.0625 \%$.and a standard deviation of 11.24202. Table 1 shows the identification of offer price and the value of the selected IPOs.

Table 1. Face value and the offer price

\begin{tabular}{llllll}
\hline & Companies number & $\begin{array}{l}\text { The Mean level of } \\
\text { price difference }\end{array}$ & $\begin{array}{l}\text { Maximum } \\
\text { no }\end{array}$ & $\begin{array}{l}\text { Minimum } \\
\text { no }\end{array}$ & Standard Deviation \\
\hline Premium & 32 & 22.0625 & 65 & 10 & 11.24202 \\
Discount & 0 & 0 & 0 & 0 & 0 \\
\hline
\end{tabular}

\subsection{Identifying Underpricing and Overpricing Level}

In this section we have identified underpricing and overpricing level within our selected time frame in Dhaka Stock Exchange. In table 2, we can see the underpricing and overpricing level within the selected time frame. It indicates underpricing level at DSE within the time frame was $198.7918 \%$. We have identified the standard deviation which is 163.8705 . Among 50 IPOs, we have found 47 were underpriced. Rest of the $3(6.4388 \%)$ were overpriced

Table 2 shows the underpricing level among our IPOs.

Table 2. Underpricing level

\begin{tabular}{llllll}
\hline & Companies number & The Mean level & $\begin{array}{l}\text { Maximum } \\
\text { no }\end{array}$ & & Minimum \\
no & Standard Deviation \\
\hline Onderpricing & 47 & 198.7918 & 666 & 4 & 163.8705 \\
Overpricing & 3 & 6.438889 & 18.4 & 0.416667 & 10.35871 \\
\hline
\end{tabular}

\subsection{Raw Level of IPO Underpricing on Yearly Basis}

Here we have arranged the raw level and market adjusted IPO underpricing. We have found the maximum number of underpricing in 2014 which is $237.5912 \%$. The standard deviation of this underpricing level is 191.2931. It is very high as we have found that, 18 firms got listed in this particular year. We have recorded the second best underpricing level in year 2012 which was $168.3375 \%$ and its standard deviation was $165.047 \%$. It happened as 10 companies have found listed in that year. The third maximum level is found in year 2015 which was $148.5643 \%$ and the standard deviation was 138.7208 . We have found 8 firms that were listed with DSE that year.

Table 3. Yearly basis raw level IPO underpricing

\begin{tabular}{llllll}
\hline Year & Companies number & The Mean level & $\begin{array}{l}\text { Maximum } \\
\text { no }\end{array}$ & $\begin{array}{l}\text { Minimum } \\
\text { no }\end{array}$ \\
\hline 2011 & 1 & 7.5 & 7.5 & 7.5 & 0 \\
2012 & 10 & 168.3375 & 420 & 0.5 & 165.0475 \\
2013 & 7 & 170.8532 & 356 & 25.33333 & 137.616 \\
2014 & 18 & 237.5912 & 666 & 13.24324 & 191.2931 \\
2015 & 8 & 148.5643 & 384 & 6 & 138.7208 \\
2016 & 3 & 158.8052 & 377 & 88 & 168.2389 \\
\hline
\end{tabular}

Source: This table is found in Islam, \& Ahmed (2010). It is the updated version. 


\subsection{Yearly Basis Market Adjusted Underpricing of IPOs}

The maximum level of market adjusted underpricing is found in 2014 . It was $231.3092 \%$. The standard deviation was $181.4965 \%$. The next best level found in year 2012 and 2015 respectively. They were $171.4431 \%$ and the standard deviation was 173.6344 .

Table 4. Adjusted IPO underpricing on yearly basis

\begin{tabular}{llllll}
\hline Year & Companies number & The Mean level & $\begin{array}{l}\text { Maximum } \\
\text { no }\end{array}$ & $\begin{array}{l}\text { Minimum } \\
\text { no }\end{array}$ & Standard Deviation \\
\hline 2011 & 1 & 6.931951 & 6.931951 & 6.931951 & 0 \\
2012 & 10 & 171.4431 & 438.1072 & 5.1809 & 173.6344 \\
2013 & 7 & 162.4175 & 307.3436 & 26.59311 & 118.6502 \\
2014 & 18 & 231.3092 & 620.4599 & 13.77567 & 181.4965 \\
2015 & 8 & 151.7518 & 376.9463 & 6.342202 & 138.9413 \\
2016 & 3 & 159.1228 & 365.778 & 96.966 & 163.3642 \\
\hline
\end{tabular}

Table. 5 Year wise market adjusted underpricing

\begin{tabular}{lll}
\hline Year & MAR & Ri \\
\hline 2011 & 6.931951 & 7.5 \\
2012 & 2801.96 & 2020.966 \\
2013 & 813.2992 & 1195.972 \\
2014 & 3695.59 & 4416.07 \\
2015 & 1031.777 & 1049.085 \\
2016 & 757.4716 & 653.6207 \\
\hline
\end{tabular}

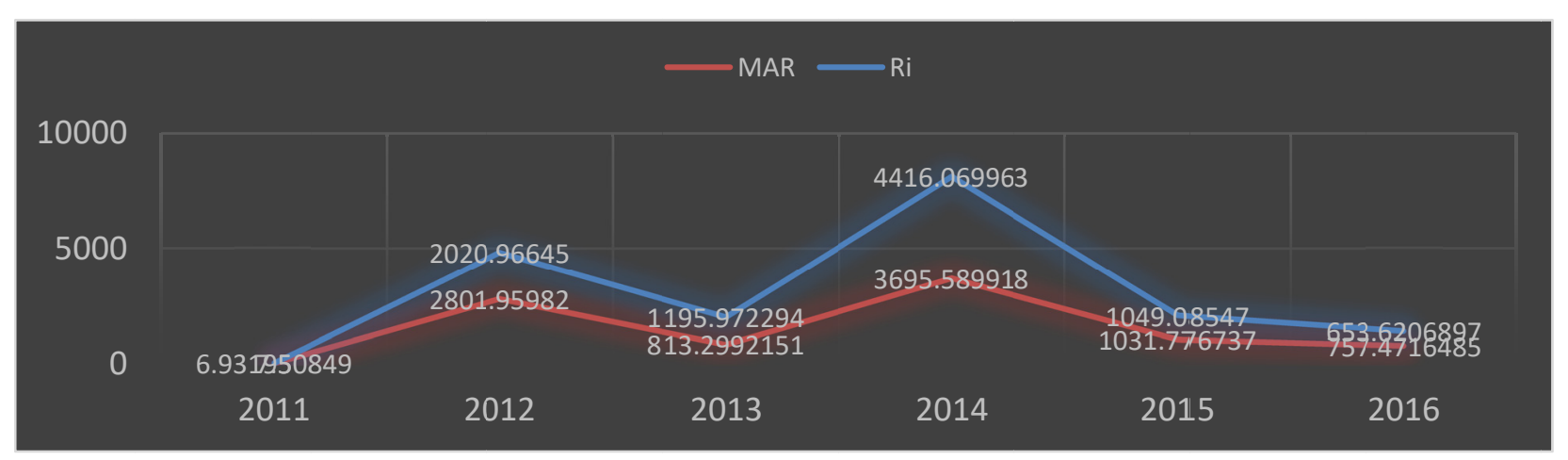

Figure 1. Year wise underpricing- Raw Vs. Market Adjusted Return

Here, Figure 1 given above identifies the relationship of market adjusted and raw level of underpricing from our selected time frame which is June 2011 to June 2016 in DSE. From the above figure we can see an identical direction was followed by both the adjusted and the raw level of underpricing. We can see, from year 2013-2014, level of underpricing faced drastic fall. It clearly indicates the volatility of IPO market which is very common in developing country like Bangladesh.

\section{Empirical Findings and Discussion}

\subsection{Model 1}

We have used OLS model for regression purpose. Here, Market adjusted abnormal return (MAAR) is considered as dependent variable. Offer time, Size of the firm, Over subscription rate were considered as the explanatory 
variable. The following econometric model 1 was used to conduct the empirical study:

$$
\text { MAR }=\alpha+\beta_{1}(\text { OT })+\beta_{2}(\text { SOF })+\beta_{3}(\text { OSR })+\mu
$$

Table 6 shows regression results of model 1. We have used STATA to get the result of this regression analysis.

\begin{tabular}{llll}
\hline Independent Variables & Co-efficient & t-statistics & Probability \\
\hline Offer Time (OT) & .1234623 & 0.20 & 0.843 \\
Size of the firm (SOF) & -76.26279 & -1.01 & 0.316 \\
Over subscription rate (OSR) & 4.773377 & 3.95 & $0.000 * *$ \\
$R^{2}$ & $55.04 \%$ & & \\
Adjusted $R^{2}$ & $52.11 \%$ & & \\
Prob> F & 0.0000 & & \\
\hline
\end{tabular}

The regression model 1 result suggests that, there are no significant relationship between size of the firm (SOF) and the level of underpricing. Here $\mathrm{P}$ value is 0.316 suggesting insignificant relationship between Size of the firm (SOF) and underpricing. Therefore alternative hypothesis 1 cannot be accepted for model 1 .

The result also shows that, relationship between over subscription rate (OSR) and market adjusted abnormal return is highly significant for model 1 . Here $\mathrm{p}$ value is 0.00 . So alternative hypothesis 4 made on this ground is accepted for this research which is consistent with the findings of Dawson (1984). Here OT (offer timing) does not have much significant effect on the level of underpricing. Therefore hypothesis 3 is not substantiated

The adjusted $\mathrm{R}$ square is $52.11 \%$. This means that size of the firm, offer timing, over subscription rate, can explain $52.11 \%$ dissimilarities.

\subsubsection{Durbin-Watson Statistic}

The Durbin-Watson statistic is a test statistic used to detect the presence of autocorrelation (a relationship between values separated from each other by a given time lag) in the residuals (prediction errors) from a regression analysis. From the test my result is following:

\section{Durbin-Watson d-statistic $(4,50)=1.807535$}

$d=1.807535$ indicates no autocorrelation. From this model we can see the result of Durbin-Watson taste lies in the range of 2.05. It is the range of acceptability. So we can conclude that the results do not have serious correlation.

\subsubsection{Variance Inflation Factor}

In our study we use variance inflation factor (VIF) to quantify the severity of multicolinearity in the defined regression analysis. This measure provides an index of the extent to which the variance of the estimated regression coefficient increases due to colinearity. The variance inflation factor of this model is presented in the table below:

\begin{tabular}{lll}
\hline Variable & VIF & $1 /$ VIF \\
\hline SOF & 2.55 & 0.392853 \\
OSR & 2.49 & 0.401275 \\
OT & 1.17 & 0.857685 \\
Mean VIF & 2.07 & \\
\hline
\end{tabular}

Normally if VIF $>10$ then multicolinearity is high. Here Mea VIF $=2.07$. So there is no serious multicolinearity problem in this model.

\subsection{Model 2}

We have used OLS model for regression purpose for model 2 also. Here, Market adjusted abnormal return (MAAR) is considered as dependent variable. Offer time, offer size, over subscription rate were considered as the explanatory variable. The following econometric model was used to conduct the empirical study:

$$
\text { MAR }=\alpha+\beta_{1}(\text { OT })+\beta_{2}(\text { OS })+\beta_{3}(\text { OSR })+\mu
$$

Table 7 shows regression results of model 1 . We have used STATA to get the result of this regression analysis. 


\begin{tabular}{llll}
\hline Independent Variables & Co-efficient & t-statistics & Prolbability \\
\hline Offer Time (OT) & -.124122 & -0.24 & 0.843 \\
Offer size (OS) & -312.2487 & -3.94 & $0.000^{* *}$ \\
Over subscription rate (OSR) & .756009 & 0.53 & 0.599 \\
$R^{2}$ & $65.64 \%$ & & \\
Adjusted $R^{2}$ & $63.40 \%$ & & \\
Prob> F & 0.0000 & & \\
\hline
\end{tabular}

The regression model 2 result suggests that, there are significant relationship between offer sizes (OS) and underpricing level. In this model, $\mathrm{P}$ values is .000 . This indicates substantial relationship with the findings. Beatty \& Ritter (1986) also found the similar result in their work. As a result we can reject null hypothesis 2.

It shows the relationship between over subscription rate (OSR) and market adjusted abnormal return in not significant. Here $\mathrm{p}$ value is 0.599 . So alternative hypothesis made on this ground is not accepted for this research. Here OT (offer timing) does not have much significant effect on the level of underpricing. Therefore alternative hypothesis 3 is not substantiated for this model 2.

The result also shows that adjusted $\mathrm{R}$ square is $63.40 \%$ which indicates we can explain $63.40 \%$ variation in the underpricing level at DSE through the help of offer timing, firm's size and the over subscription rate.

\subsubsection{Durbin-Watson Statistic}

The Durbin-Watson statistic is a test statistic used to detect the presence of autocorrelation (a relationship between values separated from each other by a given time lag) in the residuals (prediction errors) from a regression analysis. From the test my result is following:

\section{Durbin-Watson d-statistic $(4,50)=1.745995$}

$d=1.7459$ indicates no autocorrelation. From this model we can see the result of Durbin-Watson taste lies in the range of 2.05. It is the range of acceptability. So we can conclude that the results do not have serious correlation.

\subsubsection{Variance Inflation Factor}

As in the previous model, we also use variance inflation factor (VIF) here to measure the degree of multicolinearity in the second regression model. The variance inflation factor of this model is presented in the table below:

\begin{tabular}{lll}
\hline Variable & VIF & $1 /$ VIF \\
\hline OSR & 4.55 & 0.219839 \\
SOF & 4.51 & 0.22170 \\
OT & 1.07 & 0.936496 \\
Mean VIF & 3.38 & \\
\hline
\end{tabular}

Normally if VIF $>10$ then multicolinearity is high. Here Mea VIF $=3.38$. So there is no serious multicolinearity problem in this model.

\section{Conclusion \& Future Research Area}

In this paper we have tried to explain the underpricing of IPO in a developing economy that is Dhaka Stock Exchange. We have tried to incorporate various firm specific and issue related factors here. The time frame that we have taken for this purpose is from June 2011 - June 2016. From our investigation, we have identified the underpricing and overpricing factors and the difference between them. Here everything is calculated yearly basis. We have distinguished dependent and independent variables of our model by using multiple linear regression technique. We have chosen 50 listed companies within the selected time frame. Among those 50 firms, we found 47 underpriced and only 3 overpriced firm. By using two separate model, we have found that, except offer timing and firm's size, all other variables have substantial influence over IPO underpricing.

In this study it is found that, offer time and firm's size have insignificant relationship with market adjusted abnormal return which has considered underpricing. The reasons behind this insignificant relationship can be the sample size and the data set chosen for this particular study. The time frame was only last five years. Moreover, 
IPOs which were issued under fixed price method were selected for this data set. Book building method is getting popular in recent days. Further research can be done on this field considering more explanatory variables and different data set can be used to explain the relationship among these variables in future.

\section{References}

Agarwal, S., Liu, C., \& Rhee, S. G. (2008). Investor demand for IPOs and aftermarket performance": Evidence from the Hong Kong stock market. Journal of International Financial Markets, Institutions and Money, 18(2), 176-219. https://doi.org/10.1016/j.intfin.2006.09.001

Aggarwal, R. (2003). Allocation of initial public offerings and flipping activity. Journal of Financial Economics, 68(1), 111-135. https://doi.org/10.1016/S0304-405X(02)00250-7

Aggarwal, R., \& Rivoli, P. (1990). Fads in the initial public offering market. Financial Management, 19(4), 45-47. https://doi.org/10.2307/3665609

Allen, F., \& Gerald, R. F. (1989). Signaling by Underpricing in the IPO Market. Journal of Financial Economics, 23, 303-323. https://doi.org/10.1016/0304-405X(89)90060-3

Balwinder, S., \& Mittal, P. K. (2003). Underpricing of IPOs: Indian Experience. The ICFAI Journal of Applied Finance, 9(2), 29.

Bansal, R., \& Khanna, A. (2012). IPOs Underpricing and money left on the table in indian market.International Journal of Research in Management, Economics and Commerce, 2(6), 106-120.

Benveniste, L. M., \& Spindt, P. A. (1989). How investment bankers determine the offer price and allocation of new issues. Journal of financial Economics, 24(2), 343-361. https://doi.org/10.1016/0304-405X(89)90051-2

Bhabra, H. S., \& Pettway, R. H. (2003). IPO prospectus information and subsequent performance. Financial Review, 38(3), 369-397. https://doi.org/10.1111/1540-6288.00051

Booth, J., \& Chua, L. (1995). Ownership dispersion, costly information, and IPO underpricing. Journal of Financial Economics, 41, 291-310. https://doi.org/10.1016/0304-405X(95)00862-9

Brennan, M. J., \& Franks, J. (1997). Underpricing, Ownership and Control in Initial Public Offerings of Equity Securities in the UK. Journal of Financial Economics, 45(3), 391-413. https://doi.org/10.1016/S0304-405X(97)00022-6

Dawson, S. M. (1984). Overbidding for New Share Issues. Singapore Stock Exchange Journal of Finance, 14-22.

Grinblatt, M., \& Hwang, C. Y. (1989). Signalling and the Pricing of New Issues. The Journal of Finance, 44(2), 393-420. https://doi.org/10.1111/j.1540-6261.1989.tb05063.x

Hossain, M., \& Siddiquee, M. (2007). IPO Flotation Costs in Bangladesh During 1983- 2006.

Ibbotson, R. G. (1975). Price performance of common stock new issues. Journal of financial economics, 2(3), 235-272. https://doi.org/10.1016/0304-405X(75)90015-X

Islam, M., Malik, M., \& Uddin, M. (2011). Long Run Price Performance of IPO Stocks in Bangladesh. Journal of Finance and Banking, 9.

Kiymaz, H. (2000). The initial and aftermarket performance of IPOs in an emerging market: evidence from Istanbul stock exchange. Journal of Multinational Financial Management, 10(2), 213-227. https://doi.org/10.1016/S1042-444X(99)00027-4

Kumar, P. C., \& Tsetsekos, G. P. (1993). Asymmetric information, investment banking contracts and the certification hypothesis. Journal of Banking \& Finance, 17(1), 117-129. https://doi.org/10.1016/0378-4266(93)90083-P

Miller, R. E., \& Reilly, F. K. (1987). An examination of mispricing, returns, and uncertainty for initial public offerings. Financial Management, 33-38. https://doi.org/10.2307/3666001

Pagano, M., Panetta, F., \& Zingales, L. (1988). Why do firms go public? An empirical analysis. Journal of Finance, 53, 27-64. https://doi.org/10.1111/0022-1082.25448

Robinson, R. M., Robinson, M. A., \& Peng, C. C. (2004). Underpricing and IPO ownership retention. Journal of Economics and Finance, 28(1), 132-146. https://doi.org/10.1007/BF02761460

Rock, K. (1986). Why new issues are underpriced. Journal of financial economics, 15(1-2), 187-212. 
https://doi.org/10.1016/0304-405X(86)90054-1

Singh, P., \& Kumar, B. (2012). Short run and long run dynamics of initial public offerings: Evidence from India. Jindal Journal of Business Research, 1(1), 87-113. https://doi.org/10.1177/227868211200100107

Sohail, M. K., \& Nasr, M. (2007). Performance of initial public offerings in Pakistan. International Review of Business Research Papers, 3(2), 420-441.

Sohail, M. K., \& Raheman, A. (2009). Determinants of under-pricing of IPOs regarding financial \& non-financial firms in Pakistan. European Journal of Economics, Finance and Administrative Sciences, 15, 62-73.

Stoll, H. R., \& Curley, A. J. (1970). Small business and the new issues market for equities. Journal of Financial and Quantitative Analysis, 5(3), 309-322. https://doi.org/10.2307/2329998

\section{Copyrights}

Copyright for this article is retained by the author(s), with first publication rights granted to the journal.

This is an open-access article distributed under the terms and conditions of the Creative Commons Attribution license (http://creativecommons.org/licenses/by/4.0/). 